\title{
THE EMPLOYMENT OF THE MINORS IN THE CONTEXT OF EXERCISING THE CHILD'S RIGHT TO WORK
}

\begin{abstract}
Exercising the child's right to work requires a good legislative framework for labour relations and a set of conditions prescribed to ensure that the minors work in a way that does not harm their safety, health, physical, mental and moral development and does not interfere with their education. The aim of this paper is to consider both the international and national standards regulating the children's work and challenges in their application in practice. It also points out the necessary actions aimed at improving the position of the minors in the labour law environment. A special attention is paid to the issues related to the prohibition of discrimination against children in the field of work, the consent for employment including the regulation of the minimum age for employment and protection at work. The paper focuses in particular on the issue of the implementation of labour legislation in practice of Republic of Serbia, especially in the context of the efficiency of control mechanisms and the results of inspections conducted in 2019 by the Labour Inspectorate of the Ministry of Labour, Employment, Veteran and Social Affairs, which revealed a series of violations of the child's right to work. In this paper, in order to grasp an insight into this issue, there have been used the historical comparative-legal and theoretical-analytical methods. The research findings indicate that the national labour legislation
\end{abstract}

\footnotetext{
* LLD, Attorney-at-Law, Law Office Milena Banić, Belgrade, Serbia, e-mail: milena.banic@gmail.com

** PhD candidate at the Faculty of Law, The University of Business Academy in Novi Sad, Serbia, e-mail: coozy@gmail.com

(c) () (C) 2021 by the authors. This article is an open access article distributed under the terms and conditions of the Creative Commons Attribution (CC BY) license (https://creativecommons. org/licenses/by/4.0/).
} 
regulating the minors' work is harmonised with the international standards to a significant extent, but there is a room for their improvement. It is also necessary to improve the mechanisms of inspection and the efficiency of the application of legislative provisions in practice.

Keywords: the employment of the minors, the child's right to work, the protection of the minors at work, discrimination at work, consent for employment

\section{Introductory considerations}

The UN Convention on the Rights of the Child (Law on the Ratification of the Convention on the Rights of the Child, 1996), as a comprehensive and most important document in the field of child's rights, defines child as every human being below the age of eighteen years. One of the guaranteed rights in this document is the child's right to work. This includes, among other things, the obligation of states to regulate their labour legislation so that the exercise of this right does not harm the child's safety, health, physical, mental, moral and social development or interfere with the child's education. This implies providing for a minimum age for admission to employment and meeting a number of other conditions in the work environment that are specific to working children. The issue of employment of minors is an extremely complex topic and unfortunately cannot be explained by the application of standard rules, an analysis of the relevant normative substrate of a country.

In order to properly understand this issue, we must first start from the historical method and analyse the scope and type of abuses related to the work engagement of children. This issue was one of the fundamental principles of the working-class struggle to limit the work of children in the modern capitalist world, both in terms of age and in terms of work type.

The problem has to be approached also from the aspect of comparative law, because different countries still apply different regulations, and in no case can we say that all countries have accepted high international standards on the labour status of children. In African, Asian and Latin American countries, children are still widely used to perform inappropriate work for a minimum wage. In some parts of Asia, especially in poor families traditionally engaged in a craft activity, most children start working and training in the family craft at an early age, while only the oldest child is sent to school (Patrinos \& Siddiqi, 1995, pp. 2-5). This is often the case also with the families working in agriculture, which do not send children to school but engage them in work on the family farm (Mehotra \& Biggeri, 2002, p. 3). 
We shall analyse the labour status of children also from the aspect of existing non-discrimination standards. On the one hand, children must be protected from any form of discrimination in terms of inadequate pay or other forms of unequal position, while on the other hand, certain provisions must be explained from the aspect of positive discrimination.

Child labour is certainly an economic issue as well. Poor societies and families without adequate social support are forced to engage their children in work, in order to provide a subsistence. This position is usually exploited by either powerful corporations or individuals. Child labour and the prohibition of child labour ${ }^{1}$ are the top-level issues of social protection. A country that is proud of its developed social protection system will certainly have a very strict attitude towards this issue.

Child labour has to be observed and studied from the medical as well as from the psychological aspect. It is indisputable that children up to the age of eighteen are still in the process of psychophysical development, so it is strictly forbidden for children to perform work that involves high vapours, ionising radiation, high or excessively low temperatures, etc. In addition to health protection, it has to be taken into account that children are not allowed to perform work that will affect their growing up and psychological formation, such as work in casinos, night clubs, places of prostitution, etc.

This short introduction shows well how serious this issue is and how delicate it is to regulate this issue, but also to monitor the implementation of regulations, and to create the conditions that, on the one hand, ensure the child's right to work for children who need work and create appropriate working conditions, and on the other hand, prevent the abuse and exploitation of children in the work environment and ensure the protection of their rights in case of violations.

\section{Sources of law regulating child labour}

The development of the legislative framework for the protection of children in the field of labour began in the second half of the nineteenth century, in response to the serious consequences of child labour exploitation during the Industrial Revolution. This does not mean that children were not engaged in

\footnotetext{
${ }^{1}$ It should be noted that according to the International Labour Organization, the term "child labour" means the abuse of child labour in terms of the exploitation of the child, or work in conditions that harm the welfare of the child, while the terms "working children" or "economically active children" are used for children who work in adequate conditions and in accordance with prescribed standards (International Labour Organization, 2018) .
} 
difficult and inadequate forms of work even before the Industrial Revolution, especially having in mind the position of child slaves and serfs, but the labour status of children in the today's context of exercising and protecting child's rights has been present since the Industrial Revolution and the employment of children in factories, mines and other workplaces where child labour was very difficult in an unprecedented way (Kirby, 2003, p. 1).

The first laws paving the path for regulating the position of child workers and prohibiting child labour at the international level were the laws of Prussia and England adopted in the 19th century, and then followed by the legislation of many countries with the aim of preventing child exploitation and child labour in inadequate conditions, which had spread in a large number of countries across the world in different forms. However, it was not before the 20th century that child labour was explicitly prohibited at the international level and that international standards for the regulation of the position of minor workers and the protection and exercise of child's rights in the work environment were developed.

\subsection{International sources of law}

The labour status of minors is regulated under the universal sources of international law: the United Nations Convention on the Rights of the Child and the conventions adopted by the International Labour Organization, in particular the Convention no. 138 on the Minimum Age for Employment (Law on the Ratification of the International Labour Organization Convention No. 138 on the Minimum Age for Employment, 1982), the Convention no. 182. on the Worst Forms of Child Labour and the Recommendation no. 190 concerning the Prohibition and Immediate Action for the Elimination of the Worst Forms of Child Labour (Law on the Ratification of the ILO Convention no. 182 on the Worst Forms of Child Labour and ILO Recommendation no. 190 on the Prohibition and Immediate Action for the Elimination of the Worst Forms of Child Labour, 2003).

Article 32 of the United Nations Convention on the Rights of the Child guarantees protection for children against economic exploitation and labour that can be dangerous or interfere with the child's education or harm the child's health, that is, his or her physical, mental, spiritual, moral or social development. The Convention on the Rights of the Child does not define specific frameworks for the regulation of labour relations, but does instruct states to regulate this field having regard to the relevant provisions of other international instruments, in particular the conventions of the International Labour Organization. 
The International Labour Organization Convention no. 138 on the Minimum Age for Employment determines the minimum age for employment, which shall not be less than the age of completion of compulsory schooling and, in any case, shall not be less than 15 years. Exceptionally, the minimum age may be 14 years if the economy and educational facilities of a signatory state are insufficiently developed, after consultation with the organisations of employers and workers concerned (Article 2) or 13 to 15 years in case of light work which is not likely to be harmful to children's health or development or not such as to prejudice their attendance at school or their participation in vocational orientation or training programmes (Article 7). The Convention leaves the possibility to states to allow exceptions to the prohibition of employment or work in individual cases, for such purposes as participation in artistic performances, after consultation with the organisations of employers and workers concerned (Article 8). However, this provision is too general and does not contain precise regulation of the conditions under which such lowering of the age limit is allowed, or the degree of protection and inspection in such situations, in order to avoid states enabling the abuse and exploitation of younger children through an acceptable legal framework, resulting from an arbitrary interpretation of such an insufficiently precise provision.

The International Labour Organization Convention no. 182. on the Worst Forms of Child Labour requires the states to take effective measures to secure the prohibition and elimination of the worst forms of child labour as a matter of urgency. In this document, the term the worst forms of child labour comprises all forms of slavery or practices similar to slavery, including the sale and trafficking of children, debt bondage, forced labour, forced or compulsory recruitment of children for use in armed conflict, child prostitution, use of a child for illicit activities and work which, by its nature, is likely to harm the health, safety or morals of children (Article 3).

The Recommendation no. 190 concerning the Prohibition and Immediate Action for the Elimination of the Worst Forms of Child Labour defines more precisely the work that, due to its nature or circumstances in which it is performed, is harmful for the health, safety or morals of children. One of the important segments of these two documents is the recognition of the importance of preventive measures in the context of preventing the most difficult forms of child labour, such as inclusion of children in education and early recognition of risks, as well as the importance of psychosocial support for child victims of the worst forms of child labour.

As regards the international/regional sources of law, it is important to mention the Revised European Social Charter of the Council of Europe (Law 
on the Ratification of the Revised European Social Charter, 2009) and the Council Directive 94/33/EC (Council Directive 94/33/EC on the protection of young people at work, 2021).

The Revised European Social Charter also requires the states to provide that the minimum age of admission to employment shall be 15 years, subject to exceptions for children employed in prescribed light work without harm to their health, morals or education. This document is in line with the labour standards guaranteed by the International Labour Organization, but we can say that it raises these standards to a higher level by including certain additional provisions that guarantee the right to a fair remuneration, annual leave and additional health protection, and stresses the importance of paying attention to their development and education.

The Council Directive 94/33/EC on the protection of young people at work includes a set of provisions aimed at ensuring the exercise of the child's rights and their protection against economic exploitation and against any work likely to harm their safety, health or physical, mental, moral or social development or to jeopardise their education (Article 1). It comprehensively regulates the issue of exercising the child's right to work in line with the standards of the International Labour Organization, additionally specifying certain working conditions that allow their more precise incorporation into the national legislation of individual countries, such as precise determination of working time and its harmonisation with educational programmes, the obligation of free medical examination, the prohibition of performing work that carries a risk to health, as well as the prohibition of night work and the provision of exceptions in which such work is allowed.

\subsection{Domestic sources of law}

As regards the domestic sources of law governing the labour status of minors, the most important are the Constitution of the Republic of Serbia (1998), the Law on Labour (2005), the Law on Employment and Unemployment Insurance (2009), the Criminal Code (2005), the Decree on Determining Hazardous Work for Children (2017) and the Rulebook on Preventive Measures for Safe and Healthy Work of Young People (2016).

The Constitution of the Republic of Serbia determines that the minimum age for employment shall be 15 years and prohibits that persons under 18 years of age perform work detrimental to their health or morals, and guarantees the protection of children from exploitation and other risks in the work environment (Articles 66 and 64). 
The Law on Labour also determines that the minimum age for employment shall be 15 years, but a person under 18 years of age can be employed only with a written consent of his or her parent, adoptive parent or guardian provided that it does not harm his or her health, morals and education and is not prohibited by the law. Parental consent is another type of protection of the person and interests of minors and allows parents to prevent a minor from being admitted to employment if they deem that it is not in accordance with his or her well-being (Kovačević, 2017, p. 210). The requirement for the employment of a person under 18 years of age is the findings of the competent medical authority confirming his or her capability to perform the intended job and that such work is not harmful to health (Articles 24-25). Persons under the age of 18 may not perform difficult jobs that could affect their health, and include hard physical work, underground work, work under water or at high altitudes, including exposure to harmful radiation or agents that are toxic, carcinogenic and cause hereditary diseases or carry a health risk due to cold, heat, noise or vibration or may otherwise adversely affect their health and life based on the opinion of a doctor (Article 84). The law prescribes the maximum working time of 35 hours per week and 8 hours per day, while overtime or redistribution of working hours is explicitly prohibited, unless the employee under 18 years of age performs work in the field of culture, sports, art and advertising or when it is necessary to continue the work due to force majeure, if the work is such that it lasts a certain period of time and must be completed without delay, and there are not sufficient adult employees who can do the job. These provisions indicate that the Law on Labour is mainly in line with international and European standards in terms of regulating the labour status of minors, i.e. preventing the exploitation and abuse of children at work.

In order to prevent labour exploitation, Article 20 of the Law on Employment and Unemployment Insurance stipulates that the employment agency may not engage in the employment of minors or employment in jobs with increased risks. An additional degree of protection is provided by the Criminal Code, which criminalizes actions related to the labour exploitation of children or misuse of their right to work.

The Decree on Determining Hazardous Work for Children provides the protection of children from hazardous work. Hazardous work for children is defined as work that is harmful to the children's health, safety and morals, exposes them to harm and is performed in dangerous circumstances or dangerous activities for children (Article 2). This Decree specifies physical and chemical hazards for children as well as dangerous activities and circumstances in which children may not work. However, we believe that it 
should be further harmonised with other regulations governing this matter. This especially refers to the selective listing of hazardous jobs and the lack of defined parameters for determining physical and biological hazards and taking into account the child's personal characteristics such as age, sex, gender identity, health status and other characteristics (Plavšić-Nešić, A, 2017, p. 383).

\section{The Rulebook on Preventive Measures for Safe and Healthy Work} of Young People prescribes preventive measures that the employer is obliged to implement to ensure the safe work of young people and eliminate the risk of harm to the health of young people at work. Article 3 of the Rulebook provides that the employer is obliged to assess the risk of injuries and harm to health for all workplaces where young people work before the commencement of work, which includes the assessment of work organisation, exposure to harmfulness, work equipment, work processes and level of training for safe and healthy work.

\subsection{Supplementary sources}

The judicial practice in this field has developed mainly in the context of the violation of Article 4 of the European Convention for the Protection of Human Rights and Fundamental Freedoms, which refers to the prohibition of slavery and forced labour, and procedures before the European Court of Human Rights in Strasbourg. The cases in this field were related mainly to the prevention of forced labour in terms of the protection of children who are domestic help and servants and perform community services, and the prevention of child trafficking and child prostitution. ${ }^{2}$

\section{Discrimination}

Article 18 of the Law on Labour prohibits direct and indirect discrimination of job seekers and employees, on the ground of sex, birth, language, race, colour of skin, age, pregnancy, health condition, disability, ethnic origin, religion, marital status, family obligations, sexual orientation, political or other

\footnotetext{
${ }^{2}$ For more information, see the applications lodged with the European Court of Human Rights, for example: C.N. and V. v. France, Application no. 67724/09, C.N. v. the United Kingdom, Application no. 4239/08, Tiunov v. Russia, Application no. 29442/18, V.F. v. France, Application no. 7196/10, M. and Others v. Italy and Bulgaria, Application no. 40020/03, J. and Others v. Austria, Application no. 58216/12, Downloaded, 2021, June 15 from https://hudoc.echr.coe.int/eng\#\{\%22documentcoll ectionid2\%22:[\%22GRANDCHAMBER\%22,\%22CHAMBER\%22]\}.
} 
belief, social background, financial status, membership in political organisations, trade unions, or any other protected characteristic. Article 16 of the Law on the Prohibition of Discrimination (2009) also prohibits discrimination in the field of labour, in a broader way, and unlike the Law on Labour, it does not include only discrimination that is limited to persons with employment status, but covers all modalities of work engagement at all stages, including job search, employment, work engagement, as well as discrimination in connection with work engagement (Reljanović, 2004, p. 97).

In addition to the explicit prohibition of discrimination that refers to other personal characteristics, we are interested in addressing the situation related to age. In fact, if the child aged 15-18 years performs certain jobs in accordance with the employer's standards and norms, he or she may not be discriminated against in terms of salary, exercise of some basic employment rights or put in a disadvantaged position in any way. Prohibitions related to night work, certain types of work, etc. are not discriminatory in the sense of diminishing the rights of minors, but on the contrary, they should and must be interpreted as a form of state care for minors, i.e. for their proper psychophysical development through positive discrimination. The provisions that contain discriminatory elements under the Law on Labour are invalid (Reljanović, 2013, Reljanović 2010, Reljanović, 2012, Reljanović \& Petrović, 2011).

Research shows that despite the explicit prohibition of discrimination in the labour law framework, implementation in practice is a problem. The findings of a 2019 survey conducted by the Commissioner for Protection of Equality show that citizens believe that discrimination is most common in the field of work and employment, as recognised and emphasized by $74 \%$ of respondents (Commissioner for Protection of Equality, 2019, p. 23). Young people often perform non-standard forms of work, accept precarious jobs for which they are poorly paid or overqualified and where they have limited access to social security and guaranteed employment rights such as meal allowance, paid transportation to work or paid sick leave (Bradaš, 2018, p. 19). In addition, more than one fifth of the total unemployed in the Republic of Serbia are young people in the age group 15-30 (Stojanović, \& Ivković, 2020, p. 189), while according to the National Employment Service 13,844 unemployed persons in the age group 15-19 were recorded in April 2021 (National Employment Service, 2021, p. 21), which also indicates reduced youth employment opportunities and raises the issue of age discrimination and the lack of adequate programmes to provide young people with better employment opportunities. It is important to keep in mind that the issue of dignified work 
does not only mean fulfilling the economic function and the issue of equal pay for equal work, but also fulfilling the social and psychological function (Šverko, 1991, p. 17), all of which should be kept in mind when assessing discrimination of young people at work.

\section{Age as general requirement}

The general age requirement for admission to employment is 15 years. The fulfilment of this requirement is simply proven by a birth certificate, an ID card or other valid document that the minor is required to present to the employer. Since this is an imperative requirement, there can be no compromises regarding the employment before the age of 15 , or any conditional employment.

In case that a person is admitted to employment before reaching the age of 15, such employment will be considered illegal, and therefore invalid. However, the question arises as to whether persons who are under 15 years of age and are in factual employment can exercise some employment rights. Some authors believe that persons who have not fulfilled the 15-years-of-age requirement are in factual employment, and while such employment lasts, they can exercise the employment rights and fulfil the employment duties (Baltić \& Despotović, 1997, pp. 37-38; Jovanović, 2016, p. 75), while other authors consider that the failure to meet this requirement practically means the impossibility of recognising any effect since the general requirements of material importance for the existence of both labour relations and factual employment are not met (Popović, 1980, p. 100).

However, in our opinion, it would be wrong to consider that a child who has been engaged to work, even in the illegal framework, cannot get earnings, which actually motivated him or her to work. We believe that the employer may not be released from the obligation to pay the minor in accordance with the type and amount of work performed by the minor for the employer. On the other hand, however, the employer may not be released from the responsibility for the illegal engagement of workers in accordance with the general regime of misdemeanour and criminal regulations.

\section{Consent for employment of persons aged 15 to 18}

Article 25 of the Law on Labour also determines that in order for the employment of persons aged 15 to 18 to be considered valid, it is necessary to obtain a written consent of their parent, adoptive parent or guardian, and such 
work may not harm their health, morals and education, and may not be the work prohibited by the law. We will analyse these three categories.

The first refers to giving consent and who gives this consent. Here we have to refer to the provisions of the Law on Family (2005). This is because the Law on Labour was the first one that included a linguistic but also a substantial error. In fact, we can identify "legal pleonasm" in the provision in which adoptive parent is listed after parent. This is incorrect and inapplicable from the aspect of family legal protection, because after the adoption procedure, the child is treated as a child of adoptive parents and they are never mentioned as adoptive parents again, either in legal transactions or in life in general. It is completely irrelevant from the aspect of labour law whether parenthood is biological or legal, i.e. acquired through adoption, because the rights and obligations of adoptive parents after legal adoption become completely equal to the rights and obligations of parents (Šarkić \& Počuča, 2019).

It is obvious that it is absolutely enough to say that the parents give their consent for the employment of the child. If only one parent exercises the parental right, his or her consent will be sufficient. ${ }^{3}$ We consider that also in the case of divorce, a parent who does not exercise the parental right could not decide jointly with the other parent, within the meaning of Article 78 of the Law on Family, even when employment would be interpreted as an important issue (Draškić, 2007, p. 262). We believe that a 15-year-old child on whom the legislator conferred the legal capacity to be admitted to employment in this case is at the appropriate age to decide on important issues concerning him or her, and therefore there is no basis for applying this provision.

In case of children without parental care, the role of legal representative is assumed by guardians, and if a guardian is not appointed for the child, the role of a guardian is assumed by the guardianship authority.

The question also arises as to what happens in situations where one or both parents unjustifiably deny the consent for the child's employment. In that case, as in other cases where the child and his or her legal representative have conflicting interests, Article 265 of the Law on Family should be applied in terms of appointing a temporary ("collision") guardian to represent the child. In that case, the existing legal solution should be improved by defining more clearly that the lack of parental consent in case of conflicting interests of parents and children can be compensated by the consent of a temporary guardian (Kovačević \& Novaković, 2017, p. 674).

\footnotetext{
3 In case that the other parent is unknown, died, waived parental rights, is deprived of parental rights or only one parent exercises parental rights on the basis of court decision.
} 
The law did not envisage a special consent form, but in our opinion it should be a form of written statement duly signed by the parent, guardian or authorised employee of the social welfare centre. Therefore, we advocate for the introduction of a notarial form in which it will have to be accurately stated that the minor will perform certain work in a certain period of time, that he or she will receive a certain remuneration for that work, and what other rights he or she will have. We also think that the consent withdrawal form should be the same as the consent form.

\section{Types of work and protection at work}

As mentioned above, the employment of a minor requires a parental consent that protects the minor from performing jobs that are harmful to his or her psychophysical development, growing up and schooling. The legislator has introduced another criterion related to work prohibited by the law, which must also be taken into account when analysing the work of minors. The Decree on Determining Hazardous Work for Children and the Rulebook on Preventive Measures for Safe and Healthy Work of Young People defines the work that is harmful for the health, safety and morals of children, and the employer's obligations regarding the elimination of the risk of harm to the health of young people at work.

However, the Labour Inspectorate's reports to the Ministry of Labour, Employment, Veteran and Social Affairs reveal a problem in the implementation of regulations in practice. During the inspection carried out in 2019, 33 minors were found at work, including 32 persons aged 15 to 18 and one person under 15 years of age who was found working in a bakery in the production of bread and pastries. A total of 20 persons were found working under the table, without a concluded employment contract or other contract in accordance with the Law on Labour and without being registered for mandatory social insurance. The risk of injury at work for persons who work under the table is higher because they usually perform occasional and temporary jobs without professional qualifications, previous training and introduction to working process technology (Ilić, 2017, p. 69), which is additionally disconcerting in case of minors.

With respect to the persons aged 15 to 18 with whom the employers have concluded employment contracts or contracts for temporary and occasional jobs, in several cases the inspectors established the lack of a written consent of parents or the competent medical authority's findings confirming the person's capability to perform the intended job and that such work was not harmful to their health. 


\section{Concluding considerations}

Exercising the child's right to work requires a good legislative framework for labour relations, both in terms of prescribing the conditions for employment and in terms of implementing a set of measures aimed at protecting minors in the work environment. In principle, young people under the age of 18 should use their time to get education, and in the field of the child's right to education there are growing trends towards introducing compulsory secondary education. This raises the issue of enhanced protection at work with the aim of avoiding any harm to the child's education, especially taking into account new modes of youth work, such as entrepreneurship, start-ups, online jobs and other types of work that require new approaches to the protection of minors in the work environment. Work at the age of 15 to 18 is inevitable both in Serbia and in other countries of the world. This is also the reason why it is necessary to properly regulate the normative substrate in this field and to avoid all potential abuses or doubts.

We believe that control mechanisms should be improved and that the level of inspection should be enhanced in order to prevent any work of persons under the age of 18 that is not in compliance with legal regulations and that may adversely affect their development, health and education. In the process of inspection, it should be assessed whether the job can have an impact on the child's psychophysical development, the formation of his or her value judgments, the creation or loss of work habits, the creation or acquisition of negative personality traits or inadequate value systems, etc.

In our opinion, the legal concept of the employment of minors should be improved in the future also through social policy improvements in order to create conditions in which children will primarily dedicate to their own education, professional development, but also to their psychophysical development, especially having in mind the intention of introducing compulsory secondary education, as well as the importance of the correlation between education and work. 


\section{Banić Milena}

Advokat, Advokatska kancelarija Milena Banić, Beograd, Srbija

\section{Filić Miloš}

Doktorand na Pravnom fakultetu za privredu i pravosuđe, Univerzitet Privredna akademija u Novom Sadu, Srbija

\section{RADNI ODNOS MALOLETNIH LICA U KONTEKSTU OSTVARIVANJA PRAVA DETETA NA RAD}

REZIME: Ostvarivanje prava deteta na rad zahteva dobro zakonodavno uređenje radnih odnosa i propisivanje niza uslova čiji je cilj da maloletna lica rade na način da to ne ugrozi njihovu sigurnost, zdravlje, fizički, mentalni i moralni razvoj i da ne ometa njihovo obrazovanje. Cilj rada je razmatranje međunarodnih i nacionalnih standarda koji uređuju rad dece i izazova u njihovoj primeni u praksi i ukazivanje na potrebna unapređenja radi poboljšanja položaja malololetnih lica u radnopravnom okruženju. Posebna pažnja posvećena je pitanjima koja se tiču zabrane diskriminacije dece $u$ oblasti rada, davanju saglasnosti za zasnivanje radnog odnosa, uređenju minimalne starosne granice za zasnivanje radnog odnosa i zaštite na radu. Posebno se sagledava i pitanje implementacije propisanih odredbi radnopravnog zakonodavstva u praksi Republike Srbije, naročito u kontekstu efikasnosti mehanizama kontrole i rezultata vršenja inspekcijskog nadzora u 2019. godini Inspektorata za rad Ministarstva za rad, zapošljavanje, boračka i socijalna pitanja koji ukazuje na niz kršenja prava deteta na rad. Radi sagledavanja ove problematike u radu je korišćen istorijski, komparativno pravni i teorijsko-analitički metod. Rezultati istaživanja ukazuju na to da je nacionalni radnopravni okvir u oblasti rada maloletnih lica u značajnoj meri usklađen sa međunarodnim standardima, ali da postoji prostor za njihovo unapređenje. Takođe potrebno je unaprediti mehanizme nadzora i efikasnost primene zakonodavnih odredbi u praksi.

Ključne reči: radni odnos maloletnih lica, pravo deteta na rad, zaštita maloltnih lica na radu, diskriminacija na radu, saglasnost za zasnivanje radnog odnosa 


\section{References}

1. Baltić, A., \& Despotović, M. (1997). Osnove radnog prava Jugoslavije $i$ osnovni problemi sociologije rada [Fundamentals of the Labour Law of Yugoslavia and Basic Problems of Sociology of Work]. Beograd: Savremena administracija

2. Bradaš, S. (2018). Mladi i dostojanstven rad [Youth and Dignified Work]. Beograd: Fondacija Centar za demokratiju. Downloaded 2021, 15 August from http://www.centaronline.org/sr/publikacija/1785/ mladi-i-dostojanstven-rad

3. Direktiva Saveta Evropske unije 94/33/EZ o zaštiti mladih ljudi na radu [Council of the European Union Directive 94/33/EC on the protection of young people at work]. Službeni list Evropskih zajednica, br. L 216/12, Downloaded 2021, 15 August from https://eur-lex.europa.eu/ legal-content/HR/TXT/PDF/?uri=CELEX:31994L0033\&from=EN.

4. Draškić, M. (2007). Porodično pravo i prava deteta [Family Law and Child's Rights]. Beograd: Pravni fakultet Univerziteta u Beogradu

5. Ilić, M. (2017). Nadležnost Inspektorata za rad u oblasti bezbednosti i zdravlja na radu: sa osvrtom na ulogu predstavnika zaposlenih i Odbora za bezbednost i zdravlje na radu [Competence of the Labour Inspectorate in the Field of Occupational Safety and Health: With A Focus on the Role of Employee Representatives and the Occupational Health and Safety Committee]. In: Jorgić Žokić Ž. et al., (eds.) Pravo u službi sindikata, [Law in the service of trade unions] (pp. 67-74). Beograd: Samostalni sindikat metalaca Srbije

6. Jovanović, P. (2016). Zaštita mladih na radu i u vezi sa radom u međunarodnom, evropskom i pravu Srbije [Protection of Young People at Work and in Connection with Work in International, European and Serbian law]. In: Stajić, Lj. (ed.). Harmonizacija srpskog i mađarskog prava sa pravom Evropske unije: tematski zbornik: knj. 4 [Harmonisation of Serbian and Hungarian law with the European Union law : thematic collection of papers. Vol. 4] (pp. 65-77). Novi Sad: Pravni fakultet, Centar za izdavačku delatnost

7. Kovačević, Lj., \& Novaković, U. (2017). Saglasnost zakonskog zastupnika za zasnivanje radnog odnosa sa maloletnikom [Consent of Legal Representative for Employment of Minors]. Pravo i privreda, 55 (4-6), pp. $662-688$

8. Kovačević, Lj., \& Novaković, U. (2017). Univerzalni međunarodni standardi o zabrani dečijeg rada i njihova primena u pravu Republike Srbije 
[Universal International Standards on the Prohibition of Child Labour and Their Application in the Law of the Republic of Serbia]. In: Ignjatović, Đ. (ed.), Kaznena reakcija u Srbiji: tematska monografija. Deo 7 [Penal reaction in Serbia: thematic monograph. Part 7] (pp. 186-218). Beograd: Pravni fakultet Univerziteta

9. Kirby, P. (2003). Child Labour in Britain 1750-1870. Manchester: Palgrave Macmillan, University of Manchester

10. Krivični zakonik [Criminal Code]. Službeni glasnik $R S$, br. $85 / 05,88 / 05$, 107/05, 72/09, 111/09, 121/12, 104/13, 108/14, 94/16 i 35/19

11. Mehotra, S., \& Biggeri, M., (2002). The Subterranean Child Labro Force: Subcontracted home-based manufacturing in Asia. Florence: UNICEF Innocenti Research Centre

12. Međunarodna organizacija rada, Odsek za Fundamentalne principe i prava na radu. (2018). Izveštavanje medija o zloupotrebi dečijeg rada u Republici Srbiji [Media Coverage of Child Labour Abuse in the Republic of Serbia]. Ženeva: MOR. Downloaded 2021, 15 August from https:// www.ilo.org/wcmsp5/groups/public/---ed_norm/---ipec/documents/publication/wcms_667357.pdf.

13. Nacionalna služba za zapošljavanje. (2021). Nezaposlenost i zapošljavanje u Republici Srbiji [Unemployment and Employment in the Republic of Serbia Basic Abuses and Protection of Children at Work: With a Focus on the Republic of Serbia]. Mesečni statistički bilten, br. 224/2021. Downloaded 2021, 15 August from http://www.nsz.gov.rs/live/digitalAssets/15/15962_nsz_bilten_april_2021.pdf

14. Patrions, H. A., \& Siddiqi, F. (1995). Child Labour: Issues, Causes and Interventions. Washington: World Bank Human Resources Development and Operations Policy

15. Plavšić-Nešić, A. (2017). Osnove zloupotrebe i zaštite dece na radu: sa osvrtom na Republiku Srbiju [Basic abuses and protection of children at work: with reference to the Republic of Serbia]. Pravni život, 66 (11). pp. 373-388

16. Poverenik za zaštitu ravnopravnosti. (2013). Izveštaj o istraživanju javnog mnjenja - Odnos građana i građanki prema diskriminaciji u Srbiji [Public Opinion Survey Report - Attitudes of Citizens towards Discrimination in Serbia]. Beograd: Poverenik za zaštitu ravnopravnosti

17. Popović, P. (1997). Radno pravo [Labour Law]. Beograd: Službeni glasnik SFRJ

18. Porodični zakon [Law on Family]. Službeni glasnik RS, br. 18/05, 72/11, $6 / 15$ 
19. Pravilnik o preventivnim merama za bezbedan i zdrav rad mladih [Rulebook on Preventive Measures for Safe and Healthy Work of Young People]. Službeni glasnik RS, br. 102/16

20. Reljanović, M. (2004). Primena antidiskriminacionog zakonodavstva u oblasti rada [Application of Anti-discrimination Legislation in the Field of Labour]. Temida: časopis o viktimizaciji, ljudskim pravima i rodu, 17 (2), pp. 95-114

21. Reljanović, N. (2010). Zabrana diskriminacije pri zapošljavanju kao međunarodno ljudsko pravo: doktorska disertacija [Prohibition of Discrimination in Employment as an International Human Right: doctoral thesis]. Beograd: Pravni fakultet Univerziteta u Beogradu

22. Reljanović, N. (2013). Zakonsko regulisanje diskriminacije na radu $\mathrm{u}$ Republici Srbiji [Legal Regulation of Discrimination at Work in the Republic of Serbia]. In: Ivošević, Z. (ed.), Zaštita prava u oblasti rada: zbornik radova [Protection of labor rights: proceedings]. (pp. 233-260). Beograd: Glosarijum

23. Reljanović, N. (2010). Iskustva država - članica Evropske unije u sprečavanju diskriminacije pri zapošljavanju [Experiences of EU Member States in Preventing Discrimination in Employment]. Strani pravni život, (3) pp. 65-84

24. Reljanović, N. (2012). Međunarodna organizacija rada i zabrana diskriminacije [International Labour Organization and Prohibition of Discrimination]. Strani pravni život, (3), pp. 80-94

25. Reljanović, N.,\& Petrović, A., (2011). Šikanozno vršenje prava, diskriminacija i zlostavljanje na radu, zakonska regulativa i praksa [Misuse of Rights, Discrimination and Mobbing: Legal Framework and Practice]. Pravni zapisi, 2 (1), pp. 186-196

26. Ustav Republike Srbije [Constitution of the Republic of Serbia]. Službeni glasnik $R S$, br. 98/06

27. Uredba o utvrđivanju opasnog rada za decu [Decree on Determining Hazardous Work for Children]. Službeni glasnik RS, br. 53/17

28. Zakon o zabrani diskriminacije [Law on the Prohibition of Discrimination]. Službeni glasnik RS, br. 22/09 i 52/21

29. Zakon o ratifikaciji Konvencije o pravima deteta [Law on the Ratification of the UN Convention on the Rights of the Child]. Službeni list SFRJMeđunarodni ugovori, br. 15/90 i Sl. list SRJ - Međunarodni ugovori, br. $4 / 96$ i $2 / 97$

30. Zakon o ratifikaciji Konvencije Međunarodne organizacije rada br. 138 o minimalnim godinama starosti za zasnivanje radnog odnosa [Law on 
the Ratification of the International Labour Organization Convention no. 138 on the Minimum Age for Employment]. Službeni list RS SFRJ Međunarodni ugovori, br. 14/82

31. Zakon o radu [Law on Labour]. Službeni glasnik $R S$, br. 24/05, 61/05, 54/09, 32/13, 75/14, 13/17, 113/17 i 95/18

32. Zakon o zapošljavanju i osiguranju za slučaj nezaposlenosti [Law on Employment and Unemployment Insurance]. Službeni glasnik RS, br. $36 / 09,88 / 10,38 / 15,113 / 17$ i 49/21

33. Zakon o potvrđivanju Konvecije MOR broj 182 o najgorim oblicima dečijeg rada i preporuke MOR broj 190 o zabrani i hitnoj akciji za ukidanje najgorih oblika dečijeg rada [Law on the Ratification of the ILO Convention no. 182. on the Worst Forms of Child Labour and the ILO Recommendation no. 190 concerning the Prohibition and Immediate Action for the Elimination of the Worst Forms of Child Labour]. Službeni list RS SRJ-Međunarodni ugovori, br. 2/03

34. Zakon o potvrđivanju Revidirane Evropske socijalne povelje [Law on the Ratification of the Revised European Social Charter]. Službeni glasnik $R S$ - Međunarodni ugovori, br. 42/09

35. Šarkić, N. \& Počuča, M. (2019). Porodično pravo i porodičnopravna zaštita [Family Law and Family Protection]. Beograd: Službeni glasnik: Pravni fakultet Univerziteta Union

36. Šverko, B. (1991). Značenje rada u životu pojedinca: radne vrijednosti, važnost rada i alijenacija [The Meaning of Work in an Individual's Life: Work Values, Importance of Work and Alienation]. In: Kolesić, V., Krizmanić, M., Petz, B. (eds.), Uvod u psihologiju, [Introduction to psychology] (pp. 15-56). Zagreb: Prosvjeta 